\title{
STRATIGRAPHIC RELATIONS, KIMBERLITE EMPLACEMENT AND LITHOSPHERIC THERMAL EVOLUTION, QUIRICÓ BASIN, MINAS GERAIS STATE, BRAZIL
}

\author{
George Read ${ }^{1}$, Herman Grutter ${ }^{2}$, Stewart Winter ${ }^{3}$, Nigel Luckman ${ }^{1}$ and Frank Gaunt ${ }^{4}$ \\ ${ }^{I}$ Canabrava Diamond Corp., Canada $;{ }^{2}$ Mineral Services Canada Inc., Canada; \\ ${ }^{3}$ Winterbourne Explorations Inc., Canada; ${ }^{4}$ Parimá Mineração S.A., Brazil
}

\section{INTRODUCTION}

The Quiricó Basin occurs between the towns of Carmo do Paranaíba in the west, Tiros in the east and extends north of João Pinheiro in Minas Gerais State, Brazil. This Cretaceous sedimentary basin was deposited at a crucial time in the thermal evolution of the southwestern part of the São Francisco Craton and the development of the Alto Paranaíba Igneous Province (APIP). During the Cretaceous, alkaline volcanoes that form part of the APIP erupted through the recently deposited sediments of the Quiricó Basin. Field relations, petrography and geochronology show that the initial alkali volcanism was kimberlitic while the final event of the APIP was kamafugitic. Kamafugitic eruptive centres are ubiquitous in the Quiricó Basin and are far more common than true kimberlites. The kamafugites and related alkali volcanics form the Mata da Corda Group, which is the largest known occurrence of extrusive kamafugite.

This region has long been known for its high value diamonds mined from alluvial deposits associated with the Abaeté, São Bento, Areado and Tiros rivers. There are strong suggestions that the alluvial diamonds, found in the drainage systems of the Quiricó Basin, are locally

derived from kimberlite source rocks, but such sources have long eluded exploration geologists. Conceptual exploration models can be based in part on the age and stratigraphic relations of the diamondiferous Três Ranchos and Canastra kimberlites, which occur over 100 kilometers to the west of Archean rocks that define the western margin of the São Francisco craton. This setting and the relatively close proximity, in space and time, of diamondiferous kimberlites and barren kamafugites suggests a complex evolution of potentially non-Archean lithosphere below the Quiricó Basin during the Late Cretaceous.

The kimberlites and kamafugites of the APIP have transported to the surface xenocrysts, which are representative of the mantle source regions of these magmas. Some ten years of diamond exploration in this region by Canabrava Diamond Corporation has resulted in a large database of indicator mineral analyses. Clinopyroxene, specifically chrome diopside, is a peridotitic silicate that is common to both kimberlites

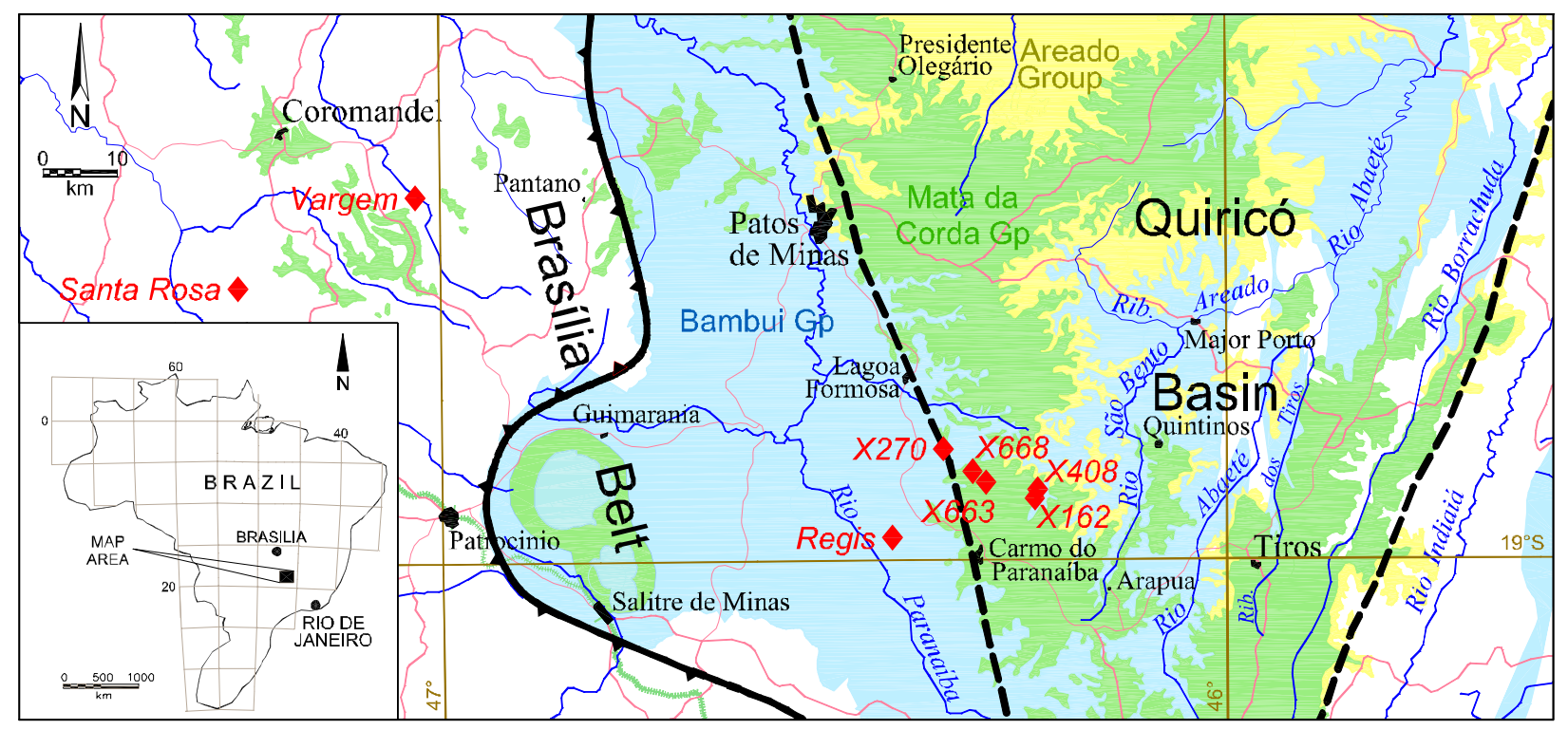

Figure 1. Map of the Quiricó Basin, Minas Gerais State, Brazil showing principal stratigraphic groups, the Brasília Belt and kimberlite and kamafugite locations. 
and kamafugites of this region. Xenocrystic clinopyroxene compositions provide insight into the relative abundance of spinel-facies or garnet-facies peridotite entrained by kimberlite and kamafugite magmas from the upper mantle. Application of the Nimis and Taylor (2000) thermobarometer to garnetfacies Cr-diopsides from kimberlites or kamafugites enables us to constrain the thermal and temporal evolution of lithospheric mantle during the Late Cretaceous infilling and development of the Quiricó Basin.

\section{STRATIGRAPHIC RELATIONS}

The Quiricó Basin is situated somewhat west of the southwestern margin of the Archean São Francisco craton. Radiometric $\mathrm{U} / \mathrm{Pb}$ dating of granitoid intrusions and greenstone belt volcanism indicates that the cratonic nucleus stabilized at $\sim 2720 \mathrm{Ma}$ (Machado et al, 1992). The conventional definition of the São Francisco craton in the literature suggests that the southwestern margin of the craton lies to the east of the cities of São Gotardo and Bambuí in central Minas Gerais. However, the occurrence of diamondiferous kimberlite at Três Ranchos-04 (95 Ma) in the west and Canastra-01 (120 $\mathrm{Ma})$ in the south indicates that, at the time of kimberlite emplacement in the Early Cretaceous, the craton was far more extensive.

The shallow marine clastic sediments of the Bambuí Group $(\sim 650 \pm 15 \mathrm{Ma})$ constitute the basement rocks underlying the Quiricó Basin. During the Late Proterozoic Brasiliano Orogeny $(700-450 \mathrm{Ma})$ the rocks of the Bambuí Group were thrust eastwards over the São Francisco cratonic basement. This was caused by the collision of the São Francisco and Amazonia cratonic nuclei during the amalgamation of the Gondwana super-continent (Gibson et al, 1995). These Proterozoic rocks are presently preserved as a succession of thrust slices known as the Brasília Belt. The Ibiá Formation rocks form the base of the Bambuí Group and consist of strongly foliated green phyllites with quartz and carbonate stringers. The remainder of the Bambuí Group is composed of slates and arkosic meta-sediments (Byron, 1999).

The Paraná Basin formed at the end of the Brasiliano Orogeny (Ordovician-Silurian) and consists of a large sedimentary basin bordering the Brasília Belt to the west. The oldest rocks within the basin are Silurian continental and marine clastic deposits and overlying Devonian shales. Sedimentation continued into the Mesozoic when approximately two-thirds of the sedimentary rocks were covered by tholeiitic lava flows erupted during the Early Cretaceous from 137 to 127 Ma (Turner et al, 1994). It is suggested that these Mesozoic continental flood basalts of the Paraná Basin were erupted as precursors to the break up of Gondwana. The lavas of the Serra Geral escarpment are part of the Paraná Basin flood basalt package.

The Quiricó Basin is situated to the east of the Paraná Basin across the Brasília Belt. The onset of Cretaceous sedimentation in the Quiricó Basin is defined by a ventifact marker horizon that has developed at the base of the Areado Group on the Early Cretaceous weathering surface of the Proterozoic Bambuí basement rocks. The Areado Group includes three formations: the Quiricó Formation (lacustrine; siltstones and argillites), the Abaeté Formation (alluvial fan; conglomerates) and the Três Barras Formation (fluvial and aeolian; arenites). Ostracodes from the lacustrine Quiricó Formation are assigned an Aptian-Albian age of 110 Ma to $115 \mathrm{Ma}$. Detailed mapping suggests that there are no Quiricó sediments east of the Rio Abaeté, with the dominant Areado unit in this region being the aeolian quartz arenite, which was deposited directly on the lag/ventifact surface on the Bambuí. This suggests that this area was elevated at the time of the Quirico sedimentation. The transition from a lacustrine arenite at the top of the Quiricó in the west to an aeolian arenite in the east suggests that the two are time equivalent. The lacustrine arenite may represent sand blown into the lake from the adjacent highland areas (Winter, 2000). While the rocks of the Quiricó, Abaeté and Três Barras are stratigraphically classified as individual formations, it is possible they represent various, more or less contemporaneous, sedimentary facies operating in adjacent parts of the depositional basin.

The Late Cretaceous volcanic rocks of the Mata da Corda Group overlie the Early Cretaceous rocks of the Areado Group. Outcrop geology consists of intrusions, flows, pyroclastic and epiclastic deposits of ultramafic / mafic composition. Exposures are intensely weathered and fresh outcrops are rare. The rocks of the Mata da Corda Group include the largest known occurrence of extrusive kamafugite. Kamafugites are silica undersaturated kalsilite-bearing lavas, which have olivine, clinopyroxene, phlogopite, melilite and kalsilite (silica depleted feldspar) as the major phases. Leucite and augite appear with increasing silica activity (Mitchell and Bergman, 1991). Sahama (1974) defined "Kamafugite" as a contraction of the names KAtungiteMAFurite-UGandite. Kamafugites differ from lamproites with respect to the degree of silica saturation as expressed petrographically by the presence of 
kalsilite and melilite and the absence of sanidine (Mitchell and Bergman, 1991).

The Mata da Corda volcanics cover an area of some 4,500 square kilometres. In areas where volcanic feeders have intruded the Areado Group Três Barras Formation arenites, the sandstones are disrupted, brecciated, fluidized and silicified (Byron, 1999). The fluidization of the Areado sandstones by the Mata da Corda volcanics may indicate that the Areado sediments were only semi-consolidated at the time of Mata da Corda volcanism. The volcanology and lithogeochemistry of the Mata da Corda volcanics has been documented in detail by Byron (1999). Literature ages for Mata da Corda volcanics are in the range of 85 to $75 \mathrm{Ma}$ (Bizzi et al, 1994 and Gibson et al, 1995).

The Mata da Corda volcanics form part of the APIP, which includes kimberlites, possible lamproites, kamafugites and carbonatites and stretches from the city of Bambuí in the southeast to the city of Rio Verde in the northwest. The features of the APIP are best described by Leonardos and Meyer (1991), Gibson et al (1995) and Carlson et al (1996). The geochemical evolution of the APIP in the Cretaceous is not well understood in spite of these review papers.

\section{KIMBERLITE EMPLACEMENT}

The recovery of many high value diamonds from placer deposits in this region motivated geologists to locate the kimberlite source rocks. Sopemi (De Beers) discovered the first kimberlites at Vargem on the Santo Inácio River in 1968. Over the next thirty years exploration programs applied the classical techniques of stream sediment sampling for indicators minerals combined with airborne and ground magnetic surveys. This exploration work resulted in the discovery of many alkali rocks, which included abundant kamafugites and rare kimberlites. The classical techniques have severe limitations as the geophysical signatures of the true kimberlites and the kamafugites are indistinguishable. Sampling for indicator minerals is complicated by the fact that both kimberlites and kamafugites produce ilmenite, spinel and clinopyroxene as abundant indicator minerals. Electron probe analysis shows that there are obvious compositional differences between the kimberlitic and kamafugitic ilmenites and spinels the kimberlitic ilmenites generally have higher $\mathrm{MgO}$ contents and the kimberlitic spinels have higher $\mathrm{Cr}_{2} \mathrm{O}_{3}$ contents than their kamafugitic counterparts. The compositional distinction between kimberlitic and kamafugitic clinopyroxenes is more complicated but, as will be explained in the next section, the compositions of clinopyroxene populations are essential to understanding the thermal evolution of the Quiricó Basin.

The number of Mata da Corda kamafugitic maar deposits far exceeds the number of true kimberlites discovered. While the ratio of kamafugites to kimberlites discovered is high, a number of true kimberlites have been discovered such as the Três Ranchos, Santa Rosa, Santa Clara, Vargem, Douradinho, Regis and X270. It is believed that these and related, but undiscovered kimberlites, are the local source rocks of the alluvial diamonds.

The X270 kimberlite pipe is at least 10 hectares in surface area and is accessible by road, some 40 kilometres south of the city of Patos de Minas. X270 was originally discovered using airborne and ground geophysics as it is capped by up to 12 metres of laterite and exhibits no local indicator mineral anomaly. By contrast, drill core samples have yielded abundant garnet, clinopyroxene, ilmenite and chromite indicator minerals. One ten-point diamond ( 0.10 carats $)$ has been recovered from a drill sample. Petrographic study classifies X270 as a crater facies, primary volcaniclastic kimberlite breccia. The mineralogy of the primary magmatic material suggests a Group 1 affinity. Accurate geochronology using $\mathrm{U}-\mathrm{Pb}$ isotopes on perovskite defined an eruption age of $89.5 \pm 3.4 \mathrm{Ma}$ for the X270 kimberlite. X270 is currently laterite capped and hosted in Proterozoic Bambuí basement. However, the kimberlite petrography reveals many arenite clasts and quartz and feldspar sand grains, which confirm the presence of overlying semi-consolidated Areado Group sediments at the time of eruption. Large Areado clasts are observed in drill core from depth.

Kimberlites and diamonds are found on both sides of the Brasília Belt. The diamondiferous Três Ranchos-04 kimberlite in the west near Catalão has been dated 95 Ma (Bizzi, 1995). The significantly diamondiferous Canastra-01 kimberlite is located in southwestern Minas Gerais, west of the Brasília Belt and has been dated at $120 \mathrm{Ma}$ (Martin Doyle, De Beers - pers. comm., 2002). The Vargem and Santa Rosa kimberlite clusters are also west of the Brasília Belt and produce high $\mathrm{Cr}_{2} \mathrm{O}_{3}$ harzburgitic and lherzolitic garnets suggesting the diamond stability field lithosphere has been sampled by these kimberlites. This study includes clinopyroxene data for two kimberlites east of the Brasília Belt: X270 and Regis. The distribution of these kimberlites suggests that the mobilization along the Brasília Belt did not affect the lithosphere. However, an 
explanation is required for the geographical juxtaposition of the petrologically different magmas of the $\sim 120$ to 89 Ma kimberlites and the $\sim 85$ to $75 \mathrm{Ma}$ kamafugites.

\section{LITHOSPHERIC THERMAL EVOLUTION}

In order to investigate the differences between mantle source regions of the kimberlites and kamafugites, this study has focused on the composition of lherzolitic clinopyroxenes, which is a peridotitic mantle mineral common to both rock types. Not only does the composition of the lherzolitic clinopyroxene provide an insight into the distinct source regions of these two alkali rock groups, but Nimis and Taylor's (2000) thermobarometer enables calculation of the thermal regimes prevailing at the time of eruption of the kimberlites and kamafugites.

During the course of diamond exploration, Canabrava Diamond Corporation compiled a large database of clinopyroxene analyses (3932 clinopyroxenes). The clinopyroxenes have been recovered predominantly from kimberlite and kamafugite rocks samples, but 64 grains from stream samples collected proximal to source rocks are also included.

All clinopyroxene compositions were reviewed and the mantle-derived lherzolitic clinopyroxenes were classified into spinel-facies or garnet-facies based on a scheme similar to that of Ramsay (1992). It was immediately noted that the Mata da Corda kamafugites carried more spinel-facies lherzolitic clinopyroxenes while the kimberlites carried many more garnet-facies clinopyroxenes. Examples are listed in Table 1.

\section{Table 1: Lherzolitic Clinopyroxene Classification Statistics}

$\begin{array}{lccc}\text { Body } & \text { Total } & \text { Gt\% } & \text { Spn \% } \\ \text { Santa Rosa } & 110 & 96 & 4 \\ \text { Vargem } & 104 & 94 & 6 \\ \text { Regis } & 56 & 93 & 7 \\ \text { X270 } & 516 & 53 & 47 \\ \text { X162 } & 98 & 89 & 11 \\ \text { X408 } & 94 & 86 & 14 \\ \text { X668 } & 118 & 86 & 14 \\ \text { X663 } & 48 & 81 & 19\end{array}$

The X270 is a true kimberlite but the proportion of spinel-facies clinopyroxene is anomalous by comparison with Santa Rosa, Vargem and Regis.

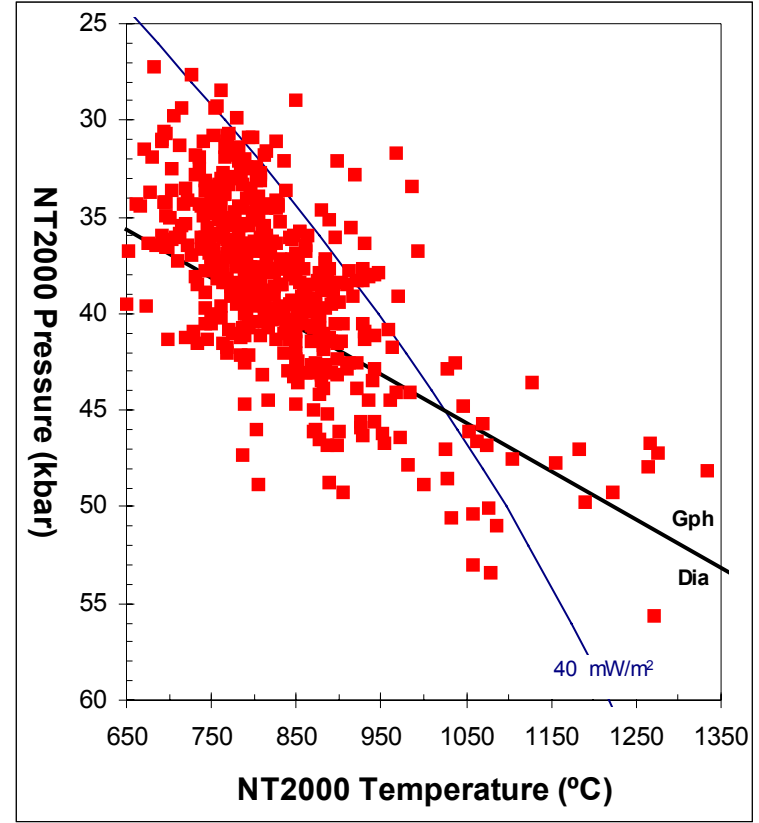

Figure 2: Pressure-temperature calculations for 517 garnetfacies clinopyroxenes from kimberlites of Time Group 1: X270, Regis, Vargem and Santa Rosa-4.

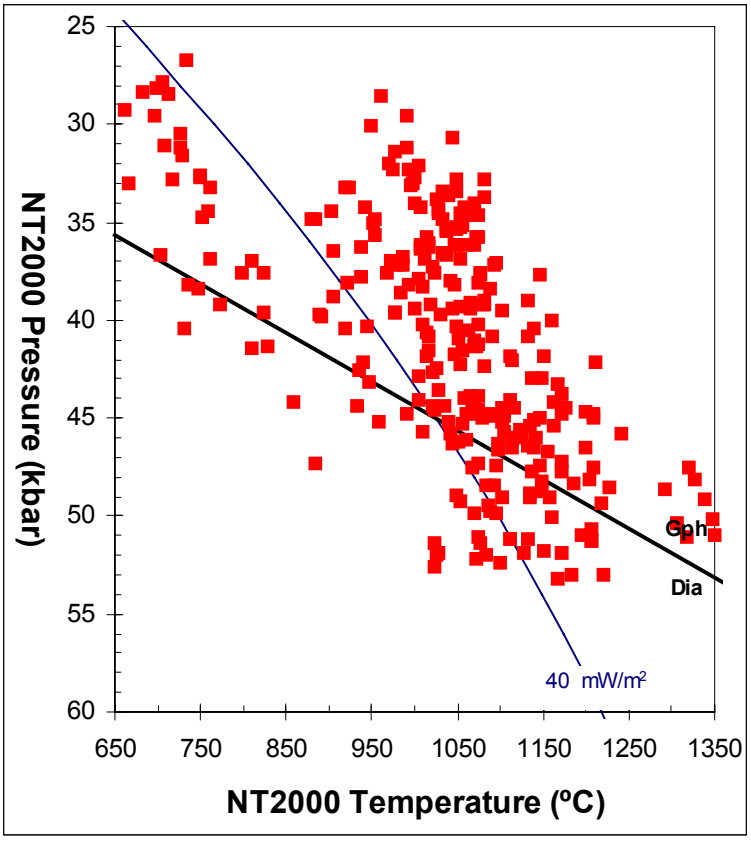

Figure 3: Pressure-temperature calculations for 296 garnetfacies clinopyroxenes from kamafugites of Time Group 2: X408, X162, X668 and X663.

Garnet-facies lherzolitic clinopyroxenes are present in both kimberlites and kamafugites. Equilibration temperatures and pressures were calculated for these clinopyroxenes using the thermobarometer of Nimis and Taylor (2000). The P-T results were divided into 
two time groups according to magmatic host type, which, in turn, correlates with age. Time Group 1 represents Early Cretaceous kimberlites Santa Rosa, Vargem, Regis and X270 and Time Group 2 represents Late Cretaceous kamafugites X408, X162, X668 and X663. The P-T results for these two Time Groups are illustrated in Figures 2 and 3, in relation to a standard $40 \mathrm{~mW} / \mathrm{m}^{2}$ cratonic geotherm. Clinopyroxenes from kimberlites define a cool craton-like geotherm and were sampled from the lithosphere in the predominant temperature range 700 to $950^{\circ} \mathrm{C}$. Grains falling in the temperature range 800 to $950^{\circ} \mathrm{C}$ were derived from inside the diamond stability field (Fig. 2). Garnet-facies clinopyroxenes from kamafugite sources, representing Time Group 2, were sampled from the mantle predominantly within a temperature interval of 800 to $1200^{\circ} \mathrm{C}$, on a geotherm that is substantially hotter than that recorded by clinopyroxenes from kimberlites (Fig. 3 ). These data imply that the lithospheric mantle underlying the Quiricó Basin was heated by $\sim 250^{\circ} \mathrm{C}$ within the time interval between $89 \mathrm{Ma}$ and about 85 Ma. We are continuing our investigation into the spatial distribution and possible temporal diachroneity of this lithospheric thermal anomaly, but can already speculate that it represents the trigger for the massive APIP alkaline magmatic event. The Late Cretaceous opening of the south Atlantic and the break-up of Gondwana is also correlated in time with this period (Bizzi - pers. com.) and rift-related extensional faulting may be seen as either a cause or an effect of the lithospheric thermal evolution below the Quiricó Basin.

\section{REFERENCES}

Bizzi, L.A., 1995. Mesozoic Alkaline Volcanism and Mantle Evolution of the Southwest São Francisco Craton, Brazil. PhD Thesis, University of Cape Town, Cape Town, South Africa.

Bizzi, L.A., Smith, C. B., Meyer, H.O.A., Armstrong, R., 1994. Mesozoic kimberlites and related rocks in southwestern São Francisco craton, Brazil: a case for local mantle reservoirs and their interaction. In: Meyer, H.O.A. and Leonardos, O.H. (Eds.), Proceedings of the $5^{\text {th }}$ International Kimberlite Conference, Araxá. Brasilia, D.F. CPRM, Special Publication 2/91, 156-177.

Byron, M.J., 1999. Physical volcanology and lithogeochemistry of the Mata da Corda Formation, Minas Gerais, Brazil. Ph.D. Thesis, Carleton University, Ottawa, Canada.

Carlson, R.W., Esperança, S., Svisero, D. P., 1996. Chemical and Os isotopic study of Cretaceous potassic rocks from Southern Brazil. Contributions to Mineralogy and Petrology 125, 393-405.

Gibson, S.A., Thompson, R.N., Leonardos, O.H., Dickin, A.P., Mithchell, J.G., 1995. The Late Cretaceous impact of the Trinidade Mantle Plume: Evidence from the large-volume, mafic, potassic magmatism in SE Brazil. Journal of Petrology 36, 189-229.

Leonardos, O.H., Meyer, H.O.A., 1991. Outline of the geology of Western Minas Gerais. Field Guide Book $5^{\text {th }}$ International Kimberlite Conference, Araxá, Brazil.

Machado, N., Noce, C.M., Ladeira, E.A., Belo de Oliveira, O., 1992. U-Pb geochronology of Archean magmatismand Proterozoic metamorphism in the Quadrilatero Ferrifero, southern São Francisco craton, Brazil. Geological Society of America Bulletin 104, 1221-1227.

Mitchell, R.H., Bergman, S.C., 1991. Petrology of Lamproites. Plenum Press, New York.

Nimis, P., Taylor, W.R., 2000. Single clinopyroxene thermobarometry for garnet peridotites. Part I. Calibration and testing of a Cr-in-Cpx barometer and an enstatite-in-Cpx thermometer. Contributions to Mineralogy and Petrology 139, 541-554.

Ramsay, R.R., 1992. Geochemistry of diamond Indicator Minerals. PhD Thesis University of Western Australia, Perth, Australia.

Sahama, T.G., 1974. Potassium-rich alkaline rocks. In: Sorenson, H. (ed.) The Alkaline Rocks. John Wiley, New York.

Seer, H.J., Moraes, L.C., Fogaca, A.C.C., 1989. Roteiro geológico para região de Lagoa FormosaChumbo-Carmo do Paranaíba, MG. Sociedade Brasileira de Geológia, Núcleo Minas Gerais, Boletim 9, 58

Turner, S., Regelous, M., Kelley, S., Hawkesworth, C., Mantovani, M., 1994. Magmatism and continental break-up in the South Atlantic: high precision ${ }^{40} \mathrm{Ar}-{ }^{39} \mathrm{Ar}$ geochronology. Earth and Planetary Science Letters 121, 333-348.

Winter, L.D.S., 2000. Stratigraphy and Maxixe units. Nova Era Mineração Ltda. Internal Company Report.

Contact: George Read, Canabrava Diamond Corporation, PO Box 10102, 1650 - 701 West Georgia Street Vancouver, B.C., Canada V7Y 1C6, E-mail: gread@canabrava.ca 